\title{
The language of a child-soldier-narrator as the voice of truth: A critical study of Ahmadou Kourouma's Allah n'est pas obligé.
}

\author{
Mawuloe Koffi KODAH, PhD \\ Department of French, University of Cape Coast, Ghana
}

\begin{abstract}
One major characteristic of the artistry of Ahmadou Kourouma as a renowned African novelist is his linguistic dexterity. In an attempt to realise the didactic function of literary works, Kourouma creates rare harmony between fiction and reality through a language that is generally representative of the socio-cultural background of the characters and the thematic orientation of his novels. Kourouma's characters are therefore always equipped with a language that reflects the socio-cultural and historical realities of the setting in which they evolve in the novels.

This study focuses on Birahima, the twelve years old child-soldier, narrator of the story of Allah n'est pas obligé, the last novel of Kourouma published in his life time in 2000, barely three years before his death in Lyon (France) in December 2003. Through a combination of the theories of utilitarianism, superiority and realism, the study critically examines the language of this child-soldier narrator in relation to the historical realities which inform the background of the story in the novel.

The study reveals that the choice of the child-soldier helps the novelist to expose the crude reality of a senseless fratricidal war in Liberian. That is, defying all diplomacy, all social taboos, all linguistic norms, Kourouma's child-soldier-narrator lays bare the unbridled truth of the atrocities and carnage that characterized the Liberian civil war and thus puts to shame the perpetrators. Combining subtle naivety with humour and sarcasm, Kourouma employs the child-soldier-narrator's language to satirize the architects of civil strife and armed conflicts in Liberia and Sierra Leone.
\end{abstract}

Key words: theory of superiority - realism - utilitarianism - child-soldier - naivety - humour - sarcasm - satire

\section{Introduction}

Language is generally defined as the human ability to communicate through speech. According to Hornby, A. S., Cowie, A. P. \& Gimson, A. C. (1974:472), language is defined as "human and instinctive method of communicating ideas, feelings and desires by means of a system of sounds and sound symbols". In of its seven definitions of language, Collins Dictionary \& Thesaurus (2000:667) considers it as "a particular manner or style of verbal expression".

Language as captured in this topic refers to the manner in which the child-soldier-narrator uses words in the expression of his thoughts in Kourouma's novel, "Allah n'est pas obligé." The study concentrates on the functionality of language usage by the child-soldier-narrator as a medium of expressing objective truth beyond mere fiction in this novel. The functionality of language usage in this study should be understood in reference narrative technique. It is conducted through a critical analysis of textual data gathered from the novel.

The study is structured in three major parts. In the first part, it establishes the characteristics and structure of this language associated with the child-soldier-narrator. The second part identifies and examines the lexical characteristic of this language which point to the determination of truth beyond fiction. This part, indeed, points out the historical indices clothed in literary creativity in the novel, in an attempt to lay bare the truth objective behind the story. Finally, the third part focuses on a critical analysis of this language in the appreciation of its truth objective through a fusion of humour, sarcasm and satire. The study is carried out in the frameworks of the theories of superiority, realism and utilitarianism.

The study is fundamentally based on textual data collected from both the original French text and its translated English version - Allah is not obliged. As a result, quotations to be exploited in the paper are in French followed by translated English version. This approach would help maintain the sanctity of some of the imageries evoked in the original French version which could not be faithfully captured in a translated version.

\section{The language of the child-soldier-narrator: characteristics and structure}

Although written, the language of the child-soldier-narrator in Kourouma's Allah n'est pas obligé is largely marked by indices of spoken language. It is mainly characterised by conversational speeches where, in the words of Brown, G. \& Yule, G. (1983:15), "sentential syntax can be observed, active declarative forms are 
normally found." The characteristics and structure of this language are identical with the age and mind-set of the child-soldier-narrator, as well as his level of formal education. Right from the word go, Birahima the childsoldier-narrator gives a clear indication as to what language register he is going to use in his narrative. He declares: "Je décide le titre définitif et complet de mon blablabla est Allah n'est pas obligé d'être juste dans toutes ses choses ici-bas. Voilà. Je commence à conter mes salades. » (Allah...: 9). This translates: "The full, final and completely complete title of my bullshit story is: Allah is not obliged to be fair about the things he does here on earth. Okay. Right. I better start explaining some stuff." (Allah is not obliged: 1) The words "blablabla" and "salades" - bullshit and stuff - are indices of informal register. They set the tone for grounding the story in figurative and colloquial language. Besides, the first person narration as marked by the "Je" - 'I' - at the start of the very first sentence of the novel, suggests a conversational language structure being set in motion by the first person singular. Indeed, this brings to mind memories of an autobiography. Eventually, the story is more or less an autobiography Birahima, a ten or twelve-year old street-child, orphan turned a child-soldier in the Liberia and Sierra Leone civil wars, in its attempt to join the maternal aunt in Liberia, following the demise of its mother.

The colloquial characteristics and conversational structure of the language of Birahima become grounded for the continuation of the story in the second paragraph of the opening chapter, as he resorts to suspense and elision, two main stylistic markers of informality in conversational language usage. He states: Et d'abord... et un... M'appelle Birahima. Suis p'tit nègre. Pas parce que suis black et gosse. Non! Mais suis p'tit nègre parce que je parle mal le français. C'é comme ça. Même si on est grand, même vieux, même arabe, chinois, blanc, russe, même américain; si on parle mal le français, on dit on parle p'tit nègre, on est p'tit nègre quand même. Ça, c'est la loi du français de tous les jours qui veut ça. (Allah ...: 9)

First off, Number one ... My name is Birahima and I'm a little nigger. Not 'cos I'm black and I'm a kid. I'm a little nigger because I can't talk French for shit. That's how things are. You might be a grown-up, or old, you might be Arab, or Chinese, or white, or Russian - or even American - if you talk bad French, it's called parler petit nègre - little nigger talking - so that makes you a little nigger too. That's the rules of French for you. (Allah is not obliged: 1)

The suspension marks '...' after "Et d'abord" and 'et un" in the original French quote above, are indices of conversational language usage. In the present situation, they translate the mental uncertainties of the childsoldier-narrator at the very beginning of his story as to how to proceed. The elision of the first person subject pronoun ' $\boldsymbol{J} \boldsymbol{e}$ ' $-\mathrm{I}$ - subsequently enhances the informal structural quality of the language. It serves the purpose of self-identification for the narrator so as to subtly constrain the virtual interlocutor, and for that matter the reader, to accept his diction and syntax. Indeed, besides being " $p$ 'tit nègre" as a result of being 'black' and 'talking bad French', Birahima is a drop-out from primary school, hence has no command over the use of French. He states this humorously but factually as follows:

... Et deux... Mon école n'est pas arrivée très loin ; j'ai coupé cours élémentaire deux. J'ai quitté le banc parce que tout le monde a dit que l'école ne vaut plus rien, même pas le pet d'une vieille grand-mère. (C'est comme ça on dit en nègre noir africain indigène quand une chose ne vaut rien. On dit que ça vaut pas le pet d'une vieille grand-mère parce que le pet de la grand-mère foutue et malingre ne fait pas de bruit et ne sent pas très, très mauvais.) (Allah ... : ibid)

Number two ... I didn't get very far at school; I gave up in my third year in primary school. I chucked it because everyone says education's not worth an old grandmother's fart any more. (In Black Nigger African Native talk, when a thing isn't worth much we say it's not worth an old grand-mother's fart, on account of how a fart from a fucked-up old granny doesn't hardly make any noise and it doesn't even smell really bad.) (Allah is not obliged: 1 - 2)

He goes further in the justification of circumstances in which he dropped out of school and why schooling is no more worth the fart of an old damned and sickly grandmother in the following words: "L'école ne vaut plus le pet de la grand-mère parce que, même avec la licence de l'université, on n'est pas fichu d'être infirmier ou instituteur dans une des républiques bananières corrompues de l'Afrique francophone." (Allah.... $9-10)$

Education isn't worth a grandmother's fart any more, because nowadays even if you get a degree you've got no hope of becoming a nurse or a teacher in some fucked-up French-speaking banana republic. ('Banana republic' means it looks democratic, but really it's all corruption and vested interests). (Allah is not obliged: 2) 
In fact, Birahima's language is what can be described as a 'linguistic salad' comprising of mixed language registers, spiced with indigenized African lexis and structure, corrupted idiomatic expressions and proverbs. This 'linguistic salad' helps to recreate the historic sociolinguistic setting in which the plot of the story evolves. Indeed, the use of a set of four different dictionaries by Birahima in an attempt to either define or explain words he humorously terms 'gros mots' - big words - for the understanding of either indigenous Africans or non-African francophones and French nationals attests to this reality. He states:

... Et cinq... Pour raconter ma vie de merde, de bordel de vie dans un parler approximatif, un français passable, pour ne pas mélanger les pédales dans les gros mots, je possède quatre dictionnaires. Primo le dictionnaire Larousse et le Petit Robert, secundo l'Inventaire des particularités lexicales du français en Afrique noire et tertio le dictionnaire Harrap's. Ces dictionnaires me servent à chercher les gros mots, à vérifier les gros mots et surtout à les expliquer. Il faut expliquer parce que mon blablabla est lire par toute sorte de gens : des toubabs (toubab signifie blanc) colons, des noirs indigènes sauvages d'Afrique et des francophones de tout gabarit (gabarit signifie genre). (Allah ... : 11)

Number five ... To make sure I tell you the life story of my fucked-up life in proper French, I've got four different dictionaries so i don't get confused with big words. First off, I've got the Larousse and the Petit Robert, then, second off, I've got the Glossary of French Lexical Particularities in Black Africa, and, third off, I've got the Harrap's. The dictionaries are for looking up big words and checking big words and particularly for explaining big words. I need to explain stuff because I want all sorts of different people to read my bullshit: colonial toubabs, Black Nigger African Natives and anyone that can understand French. (Allah is not obliged: 3 )

Birahima goes farther to demonstrate the importance of these dictionaries to the realisation of his truth objective in the story. Indeed, this demonstration exposes the universal orientation of the message Kourouma puts across through his child-soldier-narrator, the protagonist, in Allah n'est pas obligé... / Allah is not obliged.... It also gives credence to the mixed nature of the language usage by the child-soldier-narrator; hence, the express need for him to fall on the various dictionaries mentioned in order to help the various recipients of the story in the novel and outside it to understand it. This position is clearly attested to in the following words:

Le Larousse et le Petit Robert me permettent de chercher, de vérifier et d'expliquer les gros mots du français de France aux noirs nègres indigènes d'Afrique. L'Inventaire des particularités lexicales du français d'Afrique explique les gros mots africains aux toubabs français de France. Le dictionnaire Harrap's explique les gros mots pidgin à tout francophone qui ne comprend rien de rien au pidgin. (Allah...: 11)

The Larousse and the Petit Robert are for looking up and checking and explaining French words so I can explain them to Black Nigger African Natives. The Glossary of French Lexical Particularities in Black Africa is for explaining African words to the French toubabs from France. The Harrap's is for explaining pidgin words to French people who don't know shit about pidgin. (Allah is not obliged: 3 - 4)

The truth objective suggested for the child-soldier-narrator's choice of language is closely linked to the nature of historical materials - real events, settings and persons linked to the Liberia and Sierra Leone civil wars - which serve as a background information and building material for Kourouma's literary ingenuity in the novel. Interested in how Kourouma uses narrative to project his historical consciousness in Allah n'est pas obligé, $\mathrm{H}$. White (1987: 27) writes:

Narrative techniques Kourouma employs in his novel demonstrates how adept he is a using history as raw material for his fictional imagination. As characteristic in his other novels, he draws on oral narrative techniques and manipulates the French language in a manner that is typical of his writing in general.

The characteristics of this language are therefore a reflection of historical reality which is crucial to its appreciation in a literary work as Kourouma provides in Allah n'est pas oblige / Allah is not obliged... At this point, it would therefore be appropriate to closely examine some of the characteristics of the child-soldiernarrator's language as it relates to truth objective, which is the main focus of this paper.

\section{Characteristics of the child-soldier-narrator's language: Lexical characteristics}

True to his profile as a school drop-out, an insolent, fearless and indomitable street-child, Birahima's language is characterized by vulgarity, insults, deliberate exaggerations, humour, sarcasm, corrupted phrases or 
idiomatic expressions, proverbs and witty ideological denunciations, contrary to his age - ten or twelve years old. He repeatedly evokes scatological imagery and sexual obscenities to provoke laughter at the pick of human tragedy.

\section{- Scatological imagery}

Scatological imagery refers to the evocation of items or situations associated with repugnant stench, excrement. For instance, while explaining the reasons why he dropped out of school, Birahima indicates that everybody says education is no more of any value, and cannot even be compared to "the fart of an old grandmother." He says: “... J'ai quitté le banc parce que tout le monde a dit que l'école vaut plus rien, même pas le pet d'une vieille grand-mère." (Allah...: 9). The right informal idiomatic with "pet" is : "Ça ne vaut pas le pet (de lapin)». The informal English equivalent of the correct form of this idiomatic expression is "It's not worth a damn." The word "Pet" - fart - is associated with stench, bad odour; it is the bad air sent out through the anus.

The mere mention of this word evokes memories of stench, foul scent, bad odour associated with filth, decay, rot. These memories are further associated with the human anus and the entire repulsive stink it connotes - faeces, farts, stench, ugliness, etc. This foul smell subsequently becomes the dominant odour of the entire story, to efficiently evoke the nauseating smell of spilt human blood and decomposed human carcasses occasioned by the savagery of the Liberia and Sierra Leone civil wars.

Indeed Birahima is evolving in a bastardized socioeconomic and political environment which has turned him into a callous little sadist. For instance, he disdainfully presents his mother's hut, his natural habitat, in the following words: "Il y avait dans la case toutes les puanteurs. Le pet, la merde, le pipi, l'infection de l'ulcère, l'âcre de la fumée. Et les odeurs du guérisseur Balla." (Allah...: 18). "The hut was full of all kinds of stink. Farts, shit, piss, the infected ulcer, the bitter smoke, and the smell of Balla the healer." (Allah is not obliged: 10)

Ironically, he claims he does not smell the repulsive stink because of Balla the old native doctor's admonishing that "no kid ever leaves his mother's hut because her farts stink" (Allah is not obliged: 10): "... un enfant n'abandonne pas la case de sa maman à cause des odeurs d'un pet." (Allah...: 18) He declares:

But I didn't even smell them, so they didn't make me puke. Maman's stink and Balla's stink smelled good to me. I was used o them. It was surrounded by these smells that I ate and slept best. It's called a natural habitat and every animal has one; maman's hut with her smells was my natural habitat. (Allah is not obliged: 10 - 11)

The evocation of scatological imagery is intensified around the mother through a plethora of words pointing to stench, decay, nauseating smell. Among these words are:

\begin{tabular}{|l|l|}
\hline \multicolumn{1}{|c|}{ Allah n'est pas obligé... } & \multicolumn{1}{c|}{ Allah is not obliged.... } \\
\hline 'blablabla' (p. 9) & bullshit (p. 1) \\
\hline 'pet' (p. 9) & fart (p. 2) \\
\hline 'merde' (p. 10) & shit (p. 2) \\
\hline 'foutue (p. 10) & bloody awful /damn awful, fuck-up (p. 2) \\
\hline 'pourri' (p. 10) & rotten (p. 2) \\
\hline 'puanteur' (p. 18) & stink / stench (p. 10) \\
\hline 'ulcère' (p. 19) & ulcer / festering wound (p. 11) \\
\hline 'foutue et pourrie' (p. 19) & fucked-up and rotting (p. 11) \\
\hline 'lieux pourris' (p. 19) & shit-holes (p. 12) \\
\hline 'la plaie de maman' (p. 25) & her ulcer (p. 17) \\
\hline 'saigner et pourrir' (p. 25) & bleeding and rotting (p. 17) \\
\hline
\end{tabular}

A close examination of these words points to an evocation of repulsive odour associated with the decomposition, degeneration and putrefaction of Birahima's mother's physical body resulting from her ulcer. This atmosphere of nauseating stench serves as a prelude to the most nauseating stench from the macabre human and socio-political decay resulting from the savagery of the Liberian and Sierra Leonean civil wars which serve as raw material for this narrative. This in a large measure, accounts for the repeated use of the four-letter word ' $\mathrm{f} * * \mathrm{k}$ ' in various phrases in his narrative. For instance, he says: “... Fucked-up crooked republic ... [...] don't say fuck, shit ..." (p. 2); "[...] give two fucks [...] and got fucked-up on kanif [...]. Number five ... To make sure [...] the story of my fucked-up life [...]"; (p. 3); "[...] fucked-up life." (p. 4); etc. It appears this initial stinking environment which Birahima calls his 'natural habitat' has groomed him to assume a role as a child-soldier in the horrendous civil wars in the two countries. Indeed, he earlier indicates his waywardness in the nature of his diction when he says : "But I don't give two fucks about village customs any more, 'cos I've been in Liberia and 
killed lots of guys with an AK-47 (we called it a 'kalash') and got fucked-up on kanif and lots of hard drug." (Allah is not obliged: 3 ).

\section{- Sexual obscenity}

The child-soldier-narrator's language is characterised by lexical items referring explicitly or implicitly to sexual organs or sexual acts. The effect of this reference is always a source of great humour. In most case indigenized words are used then translated into English. For instance, "faforo" (my father's cock - or your father's or somebody's father's) (p. 2); "faforo" (my father's sex) (p. 5); "bilakoro" (according to the Glossary, a bilakoro is an uncircumcised boy) (p. 5); bangala (p. 49); gnoussou-gnoussou (p. 49)

In his account of what happened to their convoy to Liberia in the hands of child-soldiers, Birahima says: "The child-soldiers took our headdresses and clothes and shoes. [...] All the naked passengers from the truck unfortunately tried to cover their bangala if it was a man or their gnoussou-gnoussou if it was a woman." (Allah is not obliged: 49) As he explains in parentheses, 'bangala' and 'gnoussou-gnoussou' "are names for your shameful parts. Whereas the meanings of both words are explicit to the natives speakers, they are implicit to the non-natives speakers in their translated meanings. However, in both cases, Birahima provokes laughter.

Implicit sexual act is also evoked in the following comparison, as Birahima narrates his trepidations in the faces of the chid-soldiers: "[...] So I shut up. I was trembling, trembling like the hindquarters of a nannygoat waiting for a billy-goat. ('hindquarters' means 'arse, bum')" (Allah is not obliged: 50 -51)

Referring to Yacouba the grigriman terrified by child-soldiers, Birahima says: "His bangala had shrunk. He presents a poor nursing mother who lost her little baby in the attack as follows: "She was all filthy and she wasn't wearing her pagne any more and her underwear didn't really cover her gnoussou-gnoussou. She had a sensual charm, she had a voluptuous sex-appeal, (sex-appeal means that she made you want make love) (p. 53)

\section{- Indigenized lexical items}

The racial or tribal identity of the child-soldier-narrator is factually marked in the use of lexical items from his native Malinké origin. Besides, lexical items associated with his religious affiliation are also present to enhance the truth objective trends in the narrative. Birahima's most insulting stance and swearing are done in Malinké words. These words appear more apt to bring out the pugnacious, dare and uncompromising Malinke character traits in him. In one phase of his self-introduction, Birahima says:

Number tree ... I'm disrespectful, I'm rude as a goat's beard and I swear like a bastard. I don't swear like the civilised Black Nigger African Natives in their nice suits, I don't say fuck! Shit! Bitch! I use Malinké swear words like faforo! (my father's cock - or your father's or somebody's father's), gnamokodé! (bastard), walahé! (I swear by Allah). (Allah is not obliged: 2)

Whereas "faforo!" and "gnamokodé! as used in the above quotation give native flavour to the story and reinforce the child-soldier-narrator's attachment to his ethnic origin, "walahé!" points to his Islamic background and up-bringing. Indeed, it is at this stage that Birahima evokes one of the major root causes of social conflict all over the world and particularly in Africa: the issue of identity in its multiple forms - racial, ethnic, religious, ideological, etc. This is further manifested in economic terms, resulting into up-surge class societies - the haves and the have-nots; the rich and the poor; the literates and the illiterates; etc. This eventually leads to marginalisation and social exclusion which are latent stages of social strife. In the first place, Birahima proudly states his racial identity as follows: "Malinké is the name of the tribe I belong to." (Allah is not obliged...: 2). He then indicates the numerical strength of the Malinké tribe, as a way of extolling its importance and apparent tribal hegemony in the West African sub-region, in the following words: "They're Black Nigger African savages and there's lot of us in the north of Cote d'Ivoire and Guinea, and there's even Malinkés in other corrupt fucked-up banana republics like Gambia, Sierra Leone and up in Senegal." (Allah is not obliged...: 2 - 3)

The spread of the Malinké tribe across borders as stated in the above quotation is a subtle denunciation of the arbitrary balkanisation and disintegration of nation states, ethnic groupings into different countries by colonial powers. This process has estranged people from the same linguistic group, same family currently found in different countries, bearing different nationalities, across Africa. It is also important to underline the fact that Birahima's tribal identity as a Malinké shapes the way he perceives and projects events. This also determines the characteristics of his language.

As alluded to earlier on, the Islamic identity of Birahima is clearly established in the nature of lexical items associated with Islam. For instance, "Allah" is the very first word in the title of the novel. This is the Islamic designation for the Supreme Being, God the creator of the universe. The name "Birahima" as borne by the child-soldier-narrator is also an Islamic name. The constant repetition of the term "walahé!", (I swear by Allah), by Birahima in an attempt to give credibility to his "bullshit" throughout the text is another manifestation of his Islamic faith. However, considering the circumstances in which the swearing by Allah is done, it is obvious that Birahima rather ends up ironically defaming the name of Allah, instead of affirming his 
grandeur and righteousness. Indeed, he trivializes the Islamic belief in Allah to depict the abject bastardization of religious norms and practices in the corruption infested and war-torn states of Liberia and Sierra Leone.

\section{Syntactic structure of the child-soldier-narrator's language}

The syntactic structure of the child-soldier-narrator's language is far from the dictates of classical French language syntactic structure. Indeed, according to J. Chevrier (1994), Kourouma, when questioned on the essence of his style following the publication of his first novel, Les Soleils des Indépendances (1970), - The Suns of Independence -, replied:

Quand j'ai écrit le livre, je me suis aperçu que, dans le style classique, Fama ne ressortait pas. Je n'arrivais pas, si vous voulez, à exprimer Fama de l'intérieur, et c'est alors que j'ai essayé de trouver le style malinké [...]. Je réfléchissais en malinké, je me mettais dans la peau de Fama pour présenter la chose. (p. 143)

In the above quotation, Kourouma explains that when he wrote the book, he realized that, in classical style, Fama, the protagonist, did not come out. He, Kourouma, could not express Fama from within. It was then how he found the Malinke style. As result, he was thinking in Malinke, putting himself in the skin of Fama to present the thing.

Kourouma reiterates this position thirty years thereafter to highlight the consistency of his style as he talks his novel Allah n'est pas obligé - Allah is not obliged - in the following terms: "Mes personnages sont des Malinkés. Et lorsqu'un Malinké parle, il suit sa logique, sa façon d'aborder la réalité... » (Le Fort et Rosi in M. O. Kikukama 2012: 102). Kourouma re-echoes the fact that his characters are of Malinke extraction. Therefore, when a Malinke is speaking, he follows his own logic, his own way of handling reality. These are the underlining factors which define his usage of the French language in a peculiar way and manner in Allah n'est pas obligé.

Syntactically, Birahima's language follows the pattern of spoken language. It is full of ellipses and elisions, repetitions, and parenthetical sentences and phrases. Formal and informal language registers are mixed up to reflect the low academic status of the child-soldier-narrator and many of his like, on the one hand; and also the socioeconomic and political confusion resulting from the wars, on the other.

Considering the extensive nature of the narrative, all the main syntactic structures of English language are used at various levels from simple, compound to complex. However, we have limited our study to the Birahima's use of ellipsis and elision, repetition and parenthetical sentences and phrases.

\section{- Ellipsis and Elision}

An ellipsis results from the omission of words that can be implied to mentally complete a syntactic structure. It can also means a sudden change of subject. Elision, on the other hand, according to Nordquist, R., is: 'In phonetics and phonology, the omission of a sound (a phoneme) in speech. Elision is common in casual conversation. More specifically, elision may refer to the omission of an unstressed vowel, consonant, or syllable. This omission is often indicated in print by an apostrophe. Whereas ellipsis is a syntactic technique, elision is associated with lexical compression, and therefore is a phonetic and phonological compression. In other words, ellipsis affects the organisation of thoughts but elision effects speech.

Ellipsis in the child-soldier-narrator's language is mostly marked by three dots, and coexists with elision marked by an apostrophe to replace the suppressed unstressed vowel, consonant, or syllable. For instance, in his six points self-introduction, he declares: "First off, Number one ... My name is Birahima and I'm a little nigger. Not 'cos I'm black and I'm a kid. I'm a little nigger because I can't talk French for shit. That's how things are." (Allah is not obliged: 1) The elliptic markers combine with elision to enhance the conversational character of the syntactic structure of Birahima's language as highlighted in bolded segments in the above listed quotations. The table below captures the various forms of elision as highlighted as follows:

\begin{tabular}{|c|c|c|}
\hline Type of elision & Structure & Example \\
\hline \multirow[t]{2}{*}{ Suppression of vowel } & $\begin{array}{l}\text { I'm = I am [suppression of ' } a \text { ' replaced } \\
\text { with an apostrophe] }\end{array}$ & $\begin{array}{l}\text { "I'm a little nigger" (p. 1) } \\
\text { "I'm a kid" (p. 1); "I'm disrespectful." (p. 2); "I'm } \\
\text { rude as a goat's beard" (p. 2); “... I'm only a kid.” (p. } \\
\text { 3); “... that I'm some cute kid" (p. 4) }\end{array}$ \\
\hline & $\begin{array}{l}\text { That's }=\text { that is [suppression of ' } \mathbf{i} \text { ' from } \\
\text { verbal phrase 'is' and replaced with an } \\
\text { apostrophe] } \\
\text { "... education's not worth ... =... education } \\
\text { is not worth ... [suppression of ' } \mathbf{i} \text { ' from } \\
\text { verbal phrase 'is' and replaced with an } \\
\text { apostrophe] }\end{array}$ & $\begin{array}{l}\text { "That's how things are." (p. 1) } \\
\text { "[...] says education's not worth an old }[\ldots](\text { pp. } 1-2)\end{array}$ \\
\hline suppression of syllable & $\begin{array}{l}\text { 'cos }=\text { because [suppression of first } \\
\text { syllable 'be' and compression of the last } \\
\text { two syllable '-cause'] }\end{array}$ & $\begin{array}{l}\text { "Not'cos I'm black" (p. 1) } \\
\text { “...'cos I'm not.” (p. 4) }\end{array}$ \\
\hline
\end{tabular}

www.iosrjournals.org 


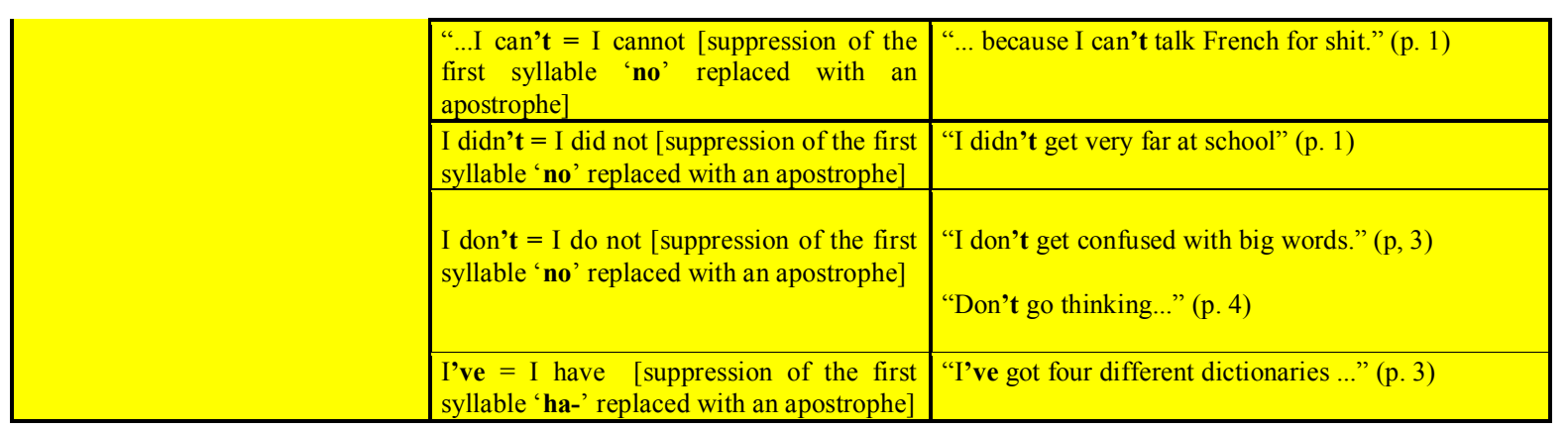

\section{- Repetitions}

Birahima uses a lot of repetitions for the sake of emphasis to draw attention to issue. The repetitions are both lexical and syntactical. For example, the word "lots" is repeatedly used to denounce the irresponsible behaviour of his grandfather as crooked businessman and womaniser:

Grandfather was a big gold trader. Like all the other filthy rich traffickers, he bought himself lots of women and horses and cows ... The women had lots of babies and the cows had a lots of calves. [...] so he bought lots of houses and lots of concessions, and when he couldn't buy more, he built more. (Allah is not obliged, 12).

The "faforo", "gnamokodé", "walahé", "fucked-up", among many others, are repeated almost on each every page. Same applies the syntactic structure "Allah is not obliged to be..." which coincidentally is the title of the novel.

Also as a form of hyperbolic denunciation, repetition is used by Kourouma to cast doubt on and denounce what he considers counter-productive to human progress, especially in religious beliefs and outdated socio-cultural practices. In this regards, Birahima explains humorously the circumstances under which her sick mother was born to justify her current state in the following words:

On the night maman was born, grandmother was too busy on account of the bad omens that were

happening all over the universe. There were lots and lots of bad omens in heaven and on earth that night - hyenas howling in the mountains, owls crying on the roofs of the huts. The omens signified that maman would have a life that was tremendously and catastrophically catastrophic. A life of shit and suffering and damnation, etc. ((Allah is not obliged...: 13)

The repetition of "lots" and the combined intensifying stylistic effects of "tremendously" and "catastrophically" to pre-modify the qualifier "catastrophic" as presented in the above quotation is a classical manifestation of a hyperbolic denunciation of the premonitory reasons for the present state his mother. It helps to cast doubt on the truthfulness of the religious beliefs underpinning such weird interpretation of natural bestial phenomena. It is rationally difficult to establish any link between the howling of hyenas and the crying of owls and the destiny of humans. However, as far as religious faith is concerned, everything is possible. This usage also brings to light the humorous denunciation of irrational religiosity which rather estranges people from the divine creator instead of drawing them nearer to him.

The use of hyperbole strengthens the truth dimension of the narrative voice of the child-soldier. The deliberate exaggeration has a humorous and ironic impact in the narrative. It therefore does not compromise the objective truth value of this voice. Rather, it affirms it through those stylistic detours. The stylistic impact of Birahima's use of hyperbole is further enhanced by the use of proverbs which have universal truth values defying time and season. Much as they are marks of adult discourse, proverbs have contributed in no small measure to the truth-objective of the child-soldier-narrator's discourse in the novel. It is therefore necessary to examine a number of them in the following paragraphs.

\section{- Proverbs}

The child-soldier-narrator uses proverbs on many occasions in his narrative. This is contrary to his presumed-naivety as a ten or twelve-year old child. These proverbs can be classified into three major groups on the basis of their functions. They are either admonishing, teaching or rebuking. By nature, proverbs are storerooms of wisdom. They are concentrated in form, with few words but have deeper meanings. Their usage is generally a mark of wisdom and knowledge in many societies. Proverbs are therefore associated with maturity. They are also universal and timeless in nature. Therefore, they are characterised by the present tense. It is quite unusual for children to use proverbs in their speech. For instance, Birahima remembers Balla's admonishing to constrain him, as child, to put up with the nauseating smell of his mother as a way of dignifying her. He recalls: "Balla used to say no kid ever leaves his mother's hut because of her farts stink." (Allah is not obliged...: 10) 


\section{- Parenthetical sentences and phrases}

One other key syntactic feature in the child-soldier-narrator's language is the use parenthetical sentences or phrases. These are explanations, definitions or ironic or humorous comments after main statements. Informative as they are, they impede free flow of thought. They are marked by:

- $\quad$ dashes -...- as in: "You might be ... Chinese, or white, or Russian - or even American - if you talk bad French, it's called parler petit nègre - little niggertalking - so that makes you a little nigger too." ( $\mathrm{p}$. $1)$;

- parentheses (...) as in : "I don't give a shit about modesty. I'm a street kid. (According to the Petit Robert, 'modesty' means 'a respect for moral standards') (p. 50)

As already alluded to, the nature and characteristics of Birahima's language is a true reflection of the social status of the French language in the African socio-cultural setting projected in the novel.

\section{The language of the child-soldier-narrator: voice of truth}

According to Paschal B. Kyiiripuo Kyoore (2004: 1), "Kourouma makes use of historical 'causality' the same way a historian does in a historical work." Kyoore further contends that "history is not merely about the distant past. Rather, history continues to manifest itself in the present as we see in Kourouma's novel." It is in this regard that he, Kyoore, suggests that “... Kourouma evokes historical personalities in order to lampoon them, and to critique dictatorship and those responsible for the civil wars in Liberia and Sierra Leone respectively." Consequently, in the words of Kyoore, "Kourouma blends history with fiction through an effective use of certain narrative techniques such as humor, proverbs, flash-backs, and the use of a diegetic picaresque-like narrative voice that speaks against injustice on behalf of the voiceless, the subaltern." Moving from the above statements, one can contend that Allah is not obliged, far from being an imaginary literary piece of work, is a historical account of the civil wars of Liberia and Sierra Leone which, in their wake, have compromised the lives and destiny of millions of innocent children. Birahima, the child-soldier-narrator, is the surviving voice of these innocent victims of the greed-driven savagery of adults.

Much as the story is a first-person narrative with a greater active participation of the narrator as the protagonist, the desire for Kourouma to privilege historical realism over mere fiction contributes to a considerable suppression of the negative impact of subjectivity associated with this type of narration. The infancy of the child-soldier-narrator also helps to mitigate the negative effect of subjectivity found in a firstperson narrative. In this respect, Birahima is a protagonist as well as an active participant-eye-witness in the carnage of civil and tribal wars in Liberia and Sierra Leone. The narrator-actor role assigned to Birahima brings to the fore the testimonial or attestation function of literary discourse as suggested by G. Genette (1972). The language of Birahima, the child-soldier-narrator in this novel of Kourouma is indeed an objective reconstruction of a deconstructed and disintegrated human society embroiled in self-destructive violence. In the words of P. Klee (...), "L'art ne reproduit pas le visible, il rend visible." (p. 34) Art indeed does not reproduce the obvious, it brings to the fore. In a talented but ruthless language, Birahima exposes the deep-rooted socioeconomic and political structural deformities underpinnings of civil wars in Liberia and Sierra Leone respectively.

Unrestrained by social taboos and sociolinguistic norms that usually canonize and regulate adult language usages, the child generally speaks its mind freely. It calls everything by its name as it sees, feels, smells, touches and tastes it. Indeed, the child is a symbol of innocence, naivety and above all, that of untainted objectivity. Unable to imagine anything at this stage of its development as a human being, the child's language is devoid of malice and capriciousness which can be associated with that of adults. Hence the high level of objectivity and credibility credited to it in discourse analysis. This is clearly demonstrated in Birahima, the child-soldier-narrator in this novel of Kourouma. In spite of the naivety associated with childhood, Birahima the child-soldier-narrator is true to the core in his presentation of events in the story as both an actor and an eyewitness. Indeed, his choice by Kourouma as the mouthpiece and protagonist of Allah n'est pas obligé, is very significant to the truth objective of the novel. Commenting on the truth objective of this novel in an article, Piavaux, M. (2004:1) writes:

Couronné par plusieurs prix littéraires, le dernier roman d'Ahmadou Kourouma nous plonge dans le quotidien des guerres tribales du Liberia et de la Sierra. Bienvenue dans le monde sanglant des massacreurs et mutilateurs de tous poils! De son ton naïf mais terriblement lucide, Birahima, "l'enfant-soldat sans peur et sans reproche " nous conte le parcours surréaliste d'un enfant de 9 ans sur les routes d'une Afrique de l'ouest à la dérive.

This quotation translates as follows:

Crowned with several literary prizes, le last novel of Ahmadou Kourouma literary plunges us into the daily world of the Liberian and Sierra Leonean tribal wars. Welcome to the bloody world of butchering and mutilation of all kind! From his naive but terribly lucid tone, Birahima, "the 
fearless and irreproachable child-soldier" recounts for us the surrealist development of a 9 yearold child on the routes of a drifting West Africa. [Our translation]

The participant-eye-witness account of a senseless human atrocity which characterizes politico-tribal wars in Liberia and Sierra Leone from the late 1980's through the early part of the $21^{\text {st }}$ century is nothing short of a chronicle of factual historical events in the form of fiction. The language of the narrator therefore vacillates between facts and fiction, reality and imagination to drive home the message of social engineering for sustainable human development in West Africa. The truth about religious irrationalism and human savagery is recounted through the voice of child to expose the derailment adults in their inordinate desire to gain socioeconomic and political power for the sake of self-aggrandisement.

The child-soldier-narrator is also the voice of traditional African belief in spirits, ghosts and fetishism. This belief however is evoked with a great deal of humorous scepticism which defies the logic of an infant. It is behind the veil of this humour that one sees the image of the writer and his ideological orientation in the narrative. Young as he is, Birahima believes that having failed to honour his mother in her life-time till she died with anger, he is cursed to suffer all kind of misfortunes, including becoming a child-soldier. He clearly states this at point six in his profile as follows:

... Et six... C'est vrai, suis pas chic et mignon, suis maudit parce que j'ai fait du mal à ma mère.

Chez les nègres noirs africains indigènes, quand tu as fâché ta maman et si elle est morte avec cette colère dans son cour elle te maudit, tu as la malédiction. Et rien ne marche chez toi avec toi. (Allah ... : 12)

Besides, he is also chased out by the spirits of the victims of his child-soldiering in the Liberia through Sierra Leone civil wars. This, he contemplates, also contributes to his predicaments as street-child compelled to live premature adult-life, through terrible life-threatening experiences. He intimates: « Suis pas chic et mignon parce que suis poursuivi par les gnamas de plusieurs personnes. » (Ibid) Conscious of the fact that the word "gnamas" is an intrusion from African origin in the French language in which the story is being written, Birahima follows this statement with a series of statements in the form of parenthetic sentences to elucidate it. He therefore explains:

(Gnama est un gros mot nègre noir africain indigène qu'il faut expliquer aux Français blancs. Il signifie, d'après Inventaire des particularités lexicales du français en Afrique noire, l'ombre qui reste après le décès d'un individu. L'ombre qui devient une force immanente mauvaise qui suis l'auteur de celui qui a tué une personne innocente.) (Allah ... : 12)

Furthermore, Birahima unambiguously reiterates his identity as an unapologetic murderer, drug addict and terrible child-soldier who is chased everywhere by misfortune. He further declares:

Et moi j'ai tué beaucoup d'innocents au Liberia et en Sierra Leone où j'ai fait la guerre tribal, où

j'ai été enfant-soldat, où je me suis bien drogue aux drogues dures. Je suis poursuivi par les

gnamas, donc tout se gâte chez moi et avec moi. Gnamakodé (bâtardise)! (Ibid.)

There is no dispute about the frankness of Birahima's historical accounts in the narrative. This frankness is enhanced by the objectivity associated with his infancy. Besides, he is participant-eye-witness in the events that serve as building material for the plot of the narrative. He is there emboldened as credible witness in recounting the events. His voice is therefore indeed that of truth. It is a loud cry from the desert calling for reflection on the plight of women and children in conflict plagued and war-torn countries across the world, particularly, Africa.

\section{Conclusion}

The critical examination of the language of Birahima the child-soldier-narrator in Kourouma's Allah n'est pas obligé reveals the aesthetic combination of indigenized French and Malinke languages to depict the true linguistic situation of standard French language usage in Africa. The linguistic identity crisis of Molière's language in the African context is a symbolic representation of the identity crisis which characterizes the state of the people of Liberia and Sierra Leone thorn apart in senseless fratricidal politico-tribal wars which serve as the plot for Kourouma's literary artistry in Allah n'est pas obligé. Uncharacteristic of his age and education, Birahima the child-soldier-narrator shows a remarkable competence in the picaresque and pictorial representation of events and acts in order to provoke readers to reflect deeply on the fate of innocent children in conflict situations as both vulnerable actors and victims.

Combining humour and sarcasm, interspersed with proverbs, metaphors and comparisons, the childsoldier-narrator gives a cinematographic account of the lives of innocent children who are tortured, raped and killed in atrocities fomented by greedy, irrational and callous adults. The apt and vivid mental pictures which flood one's mind reading the story are the trademarks of a plausible orator with an acute sense of description. It is important to raise the point that, there is a hidden voice behind that of the child-soldier-narrator. That is the reasoning voice of the master-artist whose literary mandate has been to unveil social masks of hypocrisy, irrationalism, greed and selfishness which are the bane of underdevelopment in African counties. 
As the title of the novel suggests, Allah is not obliged to be fair in all that He does here on earth. He has endowed His creation with the power to think and act reasonably for its own sustenance. Failure to do so, inevitably leads to chaos and anarchy. Blatantly naming and shaming to engender socioeconomic and political reforms is Kourouma's literary choice for calling the powers-that-be to order, so as to save Africa from drifting further into the abyss of oblivion. The child-soldier-narrator's objectivity in laying bare the truth in this quest is legendary when one considers the satirical quality of this novel.

\section{Bibliography:}

[1]. Brown, G. \& Yule, G. (1983), Discourse analysis, Cambridge University Press

[2]. Collins Dictionary \& Thesaurus (2000), Harper Collins Publishers, $2^{\text {nd }}$ Edition

[3]. Genette, G. (1972), Figure III, Paris, Edition du Seuil.

[4]. Hornby, A. S., Cowie, A. P. \& Gimson, A. C. (1974), Oxford Advanced Learner's Dictionary of Current English, Oxford University Press.

[5]. Kikukama, M. O. (2012), "Les hardiesses langagières dans Quand on refuse on dit non d'Ahmadou Kourouma"Synergies Afrique des Grands Lacs n ${ }^{\circ} 1$ - pp. 101-117

[6]. Kourouma, A. (1970), Les Soleils des indépendances Paris, Edition du Seuil.

[7]. Kourouma, A. (2000), Allah n'est pas obligé, Paris, Edition du Seuil.

[8]. Kyoore, K. B. P. (2004), "History, Political Discourse, and Narrative Strategies in the African Novel: Ahmadou Kourouma's Allah n'est pas obligé", International Third World Studies Journal and Review, Volume XV.

[9]. Piavaux, M. (2004), “Allah n'est pas obligé” (Réalité brute), Belgique, Les Territoires de la Mémoire, nº 27 - janvier-mars.

[10]. www.territoires-memoire.be/includes/am print.php?artid=263 [Consulted 1/17/2013]

[11]. White, H. (1987), The Content of the Form: Narrative discourse and Historical Representation,Baltimore, John Hopkins University Press. 